AGNIESZKA BAZYDLO

MACIEJ SMĘTKOWSKI

ANDRZEJ WIELOŃSKI

\title{
Inwestycje w specjalnych strefach ekonomicznych a przekształcenia strukturalne w przemyśle Polski
}

\section{Zmiany strukturalne w przemyśle Polski w okresie transformacji systemowej}

Zapoczątkowanej w Polsce w 1990 roku transformacji systemu gospodarczego, obejmującej przekształcenia instytucjonalno - ekonomiczne i restrukturyzację gospodarki, towarzyszyło głębokie załamanie produkcji przemysłowej. Spadek siły nabywczej społeczeństwa, zmniejszenie zapotrzebowania na dobra inwestycyjne, konkurencja wyrobów pochodzących z importu oraz rozwiązanie Rady Wzajemnej Pomocy Gospodarczej, co w efekcie doprowadziło do utraty tradycyjnych rynków zbytu i zerwania więzi kooperacyjnych, znacznie utrudniły proces przystosowywania się polskiego przemysłu do nowych warunków ekonomicznych.

Transformacja gospodarcza i integracja z Unią Europejską uwidoczniły lukę strukturalną między przemysłem polskim a przemysłem zachodnioeuropejskim.

Tab. 1 Wybrane wskaźniki charakteryzujące strukturę przemysłu w Polsce i w Unii Europejskiej

\begin{tabular}{|l|c|c|}
\hline \multicolumn{1}{|c|}{ Wyszczególnienie } & Polska & Unia Europejska \\
\cline { 2 - 3 } & \multicolumn{2}{|c|}{ W \% } \\
\hline $\begin{array}{l}\text { Udział przemysłów wysokiej techniki w produkcji prze- } \\
\text { mysłowej ogółem }\end{array}$ & $2-4$ & $14-20$ \\
\hline $\begin{array}{l}\text { Udział produkcji przemysłowej charakteryzującej się wyso- } \\
\text { ką materiałochlonnością w produkcji przemysłowej ogółem }\end{array}$ & $25-30$ & $12-15$ \\
\hline $\begin{array}{l}\text { Straty spowodowane niekorzystnym wpływem przemysłu } \\
\text { na środowisko w relacji PKB }\end{array}$ & $10-15$ & $2-4$ \\
\hline
\end{tabular}

*) Jako kryterium energochłonności i materiałochłonności przyjęto zużycie energii i stali na jednostkę produkcji

Źródło: Karpiński, Pajestka, Perczyński, 1994.

Na tle zróżnicowania wartości powyższych wskaźników za podstawowy cel strategii rozwoju przemysłu w Polsce uznano dostosowanie jego struktury do skutecznego konkurowania na jednolitym rynku europejskim.

W celu identyfikacji przekształceń zachodzących w poszczególnych gałęziach przemysłu oraz przedstawienia ogólnych tendencji zmian strukturalnych w polskim przemyśle 
w latach 1993-1998 wykorzystano przedstawioną poniżej typologię działów działalności produkcyjnej ${ }^{1}$. W sekcji działalność produkcyjna w latach 1993-1998 zatrudnienie wzrosło o $3,7 \%$ (z 2700,2 tys. do 2800,7 tys. pracowników), przy jednoczesnym wzroście wydajności pracy o $60,4 \%$. Wartości te stanowiły punkt odniesienia przy tworzeniu tej typologii.

Tab.2. Schemat typologii działów działalności produkcyjnej

\begin{tabular}{|c|c|c|c|}
\hline Dzial & Zatrudnienie „," & Zatrudnienie,$="$ & Zatrudnienie „,"” \\
\hline Wydajność „+” & $\begin{array}{c}\text { Progresywny } \\
\text { kapitałochłonny }\end{array}$ & Kapitalochłonny & $\begin{array}{l}\text { Regresywny restruktu- } \\
\text { ryzujący się }\end{array}$ \\
\hline Wydajność „="* & Progresywny & Stabilny & Regresywny \\
\hline Wydajnosć „-"* & $\begin{array}{l}\text { Progresywny } \\
\text { pracochlonny }\end{array}$ & Pracochłonny & $\begin{array}{l}\text { Regresywny } \\
\text { schyłkowy }\end{array}$ \\
\hline
\end{tabular}

* Znak „=” i „-" przy wydajności oznaczają zmianę w stosunku do średniej wydajności w działainości produkcyjnej, stąd „." nie świadczy o wartościach ujemnych, lecz znacznie mniejszych od średniej

Źródło: opracowanie własne

W latach 1993-1998 najdynamiczniej rozwijała się produkcja pojazdów mechanicznych oraz przyczep i naczep. Poza znaczącym wzrostem zatrudnienia, w zakładach działających w tej branży nastapił bardzo duży wzrost wydajność pracy - ponad dwukrotnie przewyższający średnią dla działalności produkcyjnej. Stało się tak głównie dzięki inwestycjom zagranicznych koncernów motoryzacyjnych w Polsce: Fiata w Bielsku Białej, Deawoo na Żeraniu, Volkswagena w Poznaniu i innych. Poza przemysłem motoryzacyjnym bardzo dobrze prezentowały się przedsiębiorstwa z branży celulozowej i papierniczej, w których wzrosło zatrudnienie i wydajność pracy, choć w tym drugim przypadku w stopniu znacznie mniejszym niż w pierwszej z wymienionych branż. Trzy dalsze działy osiągnęły znaczne zwiększanie zatrudnienia przy jednoczesnym wzroście wydajności na po-

\footnotetext{
' Przy tworzeniu typologii, która objęła wyłącznie działalność produkcyjną bez gómictwa i kopalnictwa oraz zaopatrywania w wodę, gaz i energię elektryczną wykorzystano dwa wskaźniki: zmianę liczby zatrudnionych $w$ danym dziale oraz zmianę wydajności pracy mierzoną wartością produkcji sprzedanej na 1 zatrudnionego. Przypisując poszczególne działy działalności produkcyjnej do poszczególnych typów analizowano po pierwsze zmiany wielkości zatrudnienia - i tak w przypadku wzrostu zatrudnienia powyżej przeciętnej dzial nazywano progresywnym, a w przypadku spadku regresywnym, a po drugie zmiany wydajności pracy - wzrost powyżej przeciętnej dział kapitałochłonny lub restrukturyzujący się (w zależności od zamiany wielkości zatrudnienia) - a wzrost mniejszy niż przeciętny dział pracochłonny lub schyłkowy (w zależności od zamiany wielkości zatrudnienia) ${ }^{1}$. Ponadto $w$ przypadkach, w których zmiana wielkości zatrudnienia oraz zmiana wydajności były zbliżone do wartości średniej dla działalności produkcyjnej wyróżniono typy pośrednie nazwane odpowiednio działem progresywnym lub regresywnym oraz kapitalochłonnym lub pracochłonnym, a także stabilnym.
} 
ziomie średnim dla działalności produkcyjnej. Dotyczyło to zwłaszcza produkcji wyrobów z gumy i tworzyw sztucznych oraz wyrobów metalowych, gdzie liczba miejsc pracy wzrosła o około $40 \%$, a w mniejszym stopniu branży produkującej maszyny i aparaturę elektryczną gdzie indziej nie sklasyfikowaną. Wspólną cechą tych gałęzi był znaczący stopień powiązania z przemysłem motoryzacyjnym.

Na drugim biegunie znalazły się tradycyjne branże takie jak: działalność wydawnicza i poligraficzna, produkcja artykułów spożywczych i napojów, mebli, drewna i wyrobów z drewna, odzieży, działalność związana z zagospodarowaniem odpadów, w których mimo znacznego przyrostu zatrudnienia wydajność pracy wzrosła w niewielkim stopniu. Oznacza to, że ich rozwój, w tym zwłaszcza produkcji mebli, drewna i odzieży, był możliwy dzięki niskim kosztom siły roboczej, a nie dużym nakładom na majątek trwały.

Przy stosunkowo stabilnym zatrudnieniu, a zatem dzięki znaczącym nakładom kapitałowym, które prowadziły do szybkiego wzrostu wydajności, rozwijała się nowoczesna produkcja maszyn biurowych i komputerów, a także instrumentów precyzyjnych: medycznych, optycznych i zegarków. Głębszą restrukturyzację wyrażającą się znacznym spadkiem zatrudnienia przechodziły produkcja aparatury radiowej, telewizyjnej i telekomunikacyjnej, produkcja innych maszyn i urządzeń oraz pozostałego sprzętu transportowego. Także w tych przypadkach wydajność wzrosła znacznie powyżej średniej. Zwłaszcza w tym ostatnim przypadku wzrost wydajności pracy można thumaczyć znacznym, przekraczającym $20 \%$ spadkiem zatrudnienia.

Największą stabilnością cechowała się produkcja wyrobów z pozostałych surowców niemetalicznych, czyli głównie materiałów budowlanych. Natomiast w kolejnych trzech działach mimo znacznego spadku zatrudnienia nie odnotowano dynamicznego (większego od średniej) zwiększenia wydajności pracy. Stało się tak w przypadku produkcji metali, tkanin oraz chemikaliów, wyrobów chemicznych i włókien sztucznych.

Tab.3. Typologia działów działalności produkcyjnej w latach 1993-1998.

\begin{tabular}{|c|c|c|c|}
\hline & ZATRUDNIENIE ,,+" & ZATRUDNIENIE,$="$ & ZATRUDNIENIE ,"-", \\
\hline 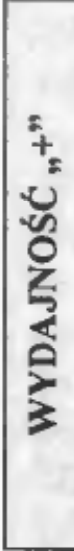 & $\begin{array}{l}\text { Produkcja pojazdów } \\
\text { mechanicznych. przy- } \\
\text { czep i naczep (148,1\%; } \\
10,8 \%)^{1} \\
\text { Produkcja masy celulo- } \\
\text { zowej, papieru } \\
\text { i wyrobów z papieru } \\
(74,7 \% ; 17,1)\end{array}$ & $\begin{array}{l}\text { Produkcja maszyn biu- } \\
\text { rowych i komputerow } \\
(243,5 \%,-2,1 \%) \\
\text { Produkcja instrumentów } \\
\text { medycznych, precyzyj- } \\
\text { nych } \\
\text { i optycznych, zegarów i } \\
\text { zegarków } \\
(94,5 \% ; 3,0 \%)\end{array}$ & 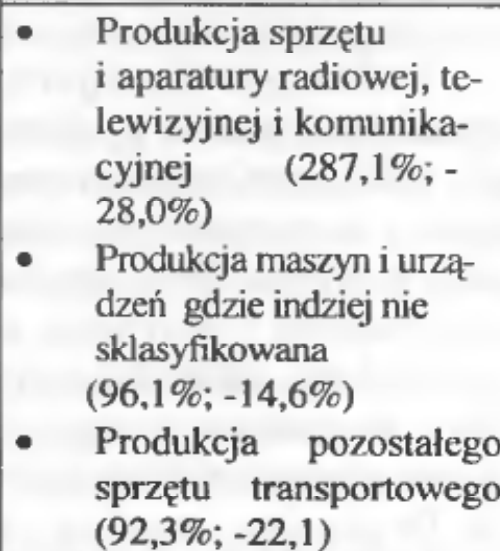 \\
\hline
\end{tabular}




\begin{tabular}{|c|c|c|c|}
\hline 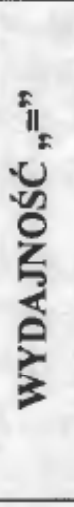 & $\begin{array}{ll}\text { Produkcja maszyn } \\
\text { i aparatury elektrycznej, } \\
\text { gdzie indziej nie sklasy- } \\
\text { fikowanych } \\
(60,9 \% ; 13,61 \%) \\
\text { Produkcja metalowych } \\
\text { wyrobów gotowych } \\
(57,0 \% ; 37,1 \%) \\
\text { Produkcja wyrobów z } \\
\text { gumy i tworzyw sztucz- } \\
\text { nych }(54,3 \% ; 42,1 \%) \\
\end{array}$ & $\begin{array}{l}\text { Produkcja wyrobów } \\
\text { z pozostałych surowców } \\
\text { niemetalicznych } \\
(64,4 \% ;-0.9 \%)\end{array}$ & $\begin{array}{ll}\text { - } & \text { Produkcja metali } \\
& (71,9 \% ;-17,8 \%) \\
\text { - } & \text { Produkcja tkanin } \\
& (64,0 \% ;-25,5 \%) \\
\text { - } & \text { Produkcja chemikaliow, } \\
\text { wyrob6w chemicznych } \\
\text { i włókien sztucznych } \\
(54.7 \% ;-4,0 \%)\end{array}$ \\
\hline 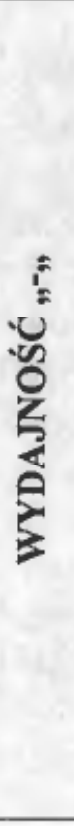 & $\begin{array}{ll}\text { - } & \text { Działalność wydawnicza } \\
\text { i poligraficzna } \\
(44,2 \% ; 38,1) \\
\text { - } \\
\text { Produkcja artykułów } \\
\text { spożywczych i napojów } \\
(40,7 \% ; 9,4 \%) \\
\text { - Produkcja mebli, dzia- } \\
\text { łalności gdzie indziej nie } \\
\text { sklasyfikowana } \\
\text { (28,9\%; 37,1\%) } \\
\text { Produkcja drewna } \\
\text { i wyrobów z drewna } \\
\text { (28,5\%, 28,3\%) } \\
\text { Produkcja odzieży } \\
(27,0 \% ; 12,9 \%) \\
\text { Zagospodarowanie } \\
\text { odpadów } \\
(2,3 \% ; 40,7 \%) \\
\end{array}$ & & $\begin{array}{ll}\text { - } & \text { Garbowanie i wypra- } \\
\text { wianie skór, produkcja } \\
\text { toreb i obuwia } \\
(47,3 \% ;-19,9 \%) \\
\text { - } \quad \text { Produkcja wyrobów } \\
\text { tytoniowych } \\
(23,8 \% ;-8,3 \%) \\
\text { - Wytwarzanie produktów } \\
\text { koksowania węgla, pro- } \\
\text { duktów rafinacji ropy } \\
\text { naftowej } \\
\text { i paliw jądrowych } \\
(14,4 \% ;-8,5 \%)\end{array}$ \\
\hline
\end{tabular}

'(zmiana wydajności, zmiana zatrudnienia)

Źródło: opracowanie wlasne podstawie danych GUS

Trudna sytuacja, objawiająca się znacznym spadkiem zatrudnienia przy jednoczesnym niewielkim wzroście wydajności pracy, miała miejsce w działalności związanej z przemysłem skórzanym, tytoniowym oraz koksownictwem węgla i rafinacją ropy naftowej. Może oznaczać to poważne problemy zwłaszcza dla pierwszej z tych branż, w której zatrudnienie spadło o prawie $20 \%$, a wzrost wydajności był znacznie niższy od przeciętnego. W przypadku ostatniej z tych branż zaistniałą sytuację można tłumaczyć zaniechaniem znaczących przekształceń własnościowych. Ciekawa jest sytuacja przemysłu tytoniowego, w którym mimo zaangażowania zagranicznych koncernów w zakładach tej branży wydajność pracy wzrosła nieznacznie, mimo 8\% spadku zatrudnienia. Można to tłumaczyć na kilka sposobów. Po pierwsze stopniowo w Polsce spada zainteresowanie paleniem papierosów, z czym wiąże się spadek wartości sprzedaży. Spadek ten jest dodatkowo wzmacniany przemytem papierosów przez granicę. Z drugiej strony w przemyśle tytoniowym pracuje zaledwie około 11 tysięcy osób, tak że nawet niewielkie zmniejszenie zatrudnienia wyraża się wysokim odsetkiem w stosunku do ogółu pracujących. 


\section{Specjalne strefy ekonomiczne - narzędzie lagodniejszej restrukturyzacji}

Niedopasowania strukturalne i kumulacja negatywnych skutków przemian społeczno - gospodarczych, których skala znacznie przekraczała lokalne możliwości wymagała ogólnokrajowych rozwiązań. Wyrazem pomocy państwa była ustawa z 20 października 1994r. powołująca specjalne strefy ekonomiczne do rangi instrumentu ułatwiającego przystosowanie polskiej gospodarki do zasad wolnorynkowych. W świetle powyższej ustawy państwo tworzy specjalną strefę ekonomiczną w celu aktywizacji gospodarczej regionu, głównie poprzez zaangażowanie zewnętrznych inwestorów strategicznych. Magnesem przyciągającym ich kapitał i technologie ma być preferencyjna polityka podatkowa dla określonych dziedzin działalności gospodarczej, w szczególności tych, które gwarantują optymalne warunki rozwoju lokalnego. Ustawa o specjalnych strefach ekonomicznych podkreśla ich rolę jako czynnika przyśpieszającego rozwój gospodarczy części terytorium kraju, poprzez realizację określonych celów tj.:

- Rozwój określonych dziedzin działalności gospodarczej,

- Rozwój nowych rozwiązań technicznych i technologicznych oraz ich wykorzystanie w gospodarce narodowej,

- Rozwój eksportu,

- Zwiększenie konkurencyjności wytwarzanych wyrobów i świadczonych usług,

- Zagospodarowanie istniejącego majątku przemysłowego i infrastruktury gospodarczej,

- Tworzenie nowych miejsc pracy, zagospodarowanie nie wykorzystanych zasobów naturalnych z zachowaniem zasad równowagi ekologicznej

Tak sformułowane cele stawiane przed specjalnymi strefami ekonomicznymi sugerują, że mają one rangę instrumentu realizacji polityki przemysłowej, opierającej się na rozwoju określonych branż przemysłowych, transferze nowoczesnych rozwiązań technologicznych i wspieraniu produkcji proeksportowej. Jednocześnie bezsprzecznie podstawowy cel ich powołania zdefiniowany jako walka z pogłębiającym się strukturalnym bezrobociem jest dowodem na rolę stref w rozwiązywaniu problemów regionalnych. Powyższe cele potwierdzają tezę, że specjalne strefy ekonomiczne pełnią znaczącą rolę w przekształceniach strukturalnych przestrzeni przemysłowej Polski ${ }^{2}$.

Główną zachętą do prowadzenia działalności na terenie strefy są zwolnienia podatkowe. Dochody uzyskane z działalności gospodarczej, prowadzonej na terenie strefy na podstawie zezwolenia uzyskanego do 31 grudnia 2000 roku$^{3}$, są całkowicie zwolnione z podatku dochodowego przez połowę okresu, na jaki została ustanowiona strefa (większość stref

\footnotetext{
${ }^{2} \mathrm{~W}$ istocie wskutek przekazania przez Ministerstwo Gospodarki prawa do wydawania zezwoleń spółkom zarządzającym strefami moźliwość doboru inwestorów pod kątem wpływu na przekształcenia strukturalne przemysłu, pomimo zapisu o preferowanych branżach działalności gospodarczej w rozporządzeniach powołujących strefy, została znacznie ograniczona.

${ }^{3}$ Od 1 stycznia 2001 roku obowiązuje znowelizowana Ustawa o specjalnych strefach ekonomicznych. Według zmienionych zasad inwestorzy, którzy rozpoczną działalność w strefach mają zagwarantowaną ( $w$ przeciwieństwie do podmiotów zlokalizowanych poza strefami) pomoc publiczną wynikającą z Ustawy o pomocy publicznej. Należy jednak pamiętać, że w świetle w/w Ustawy przedsiębiorcy mogą liczyć na skorzystanie z przywilejów podatkowych jedynie do wysokości $50 \%$ wartości podjętych inwestycji.
} 
powołano na okres 20 lat, wyjątek stanowią technoparki, których okres działania skrócono do 12 lat), a w pozostałym okresie zwolnione w części nie przekraczającej $50 \%$ dochodów. Warunkiem nabycia powyższego prawa do preferencji podatkowych jest albo zatrudnienie określonej liczby pracowników albo poniesienie określonych nakładów inwestycyjnych (obie wartości są zapisane w rozporządzeniu ustanawiającym daną strefę) ${ }^{4}$. W przypadku podmiotów gospodarczych nie posiadających prawa do zwolnień $\mathrm{z}$ podatku dochodowego preferencje obejmują: możliwość zaliczenia wydatków inwestycyjnych do kosztów uzyskania przychodu oraz możliwość podwyższenia stawki amortyzacji środków trwałych służących prowadzeniu działalności gospodarczej na terenie strefy. Ponadto w strefach znacznie uproszczono przepisy dotyczące otrzymywania zezwoleń budowlanych (decyzje w tym zakresie podejmuje zarządzający strefa), a także zastosowano szybsze procedury nabywania nieruchomości przez obcokrajowców.

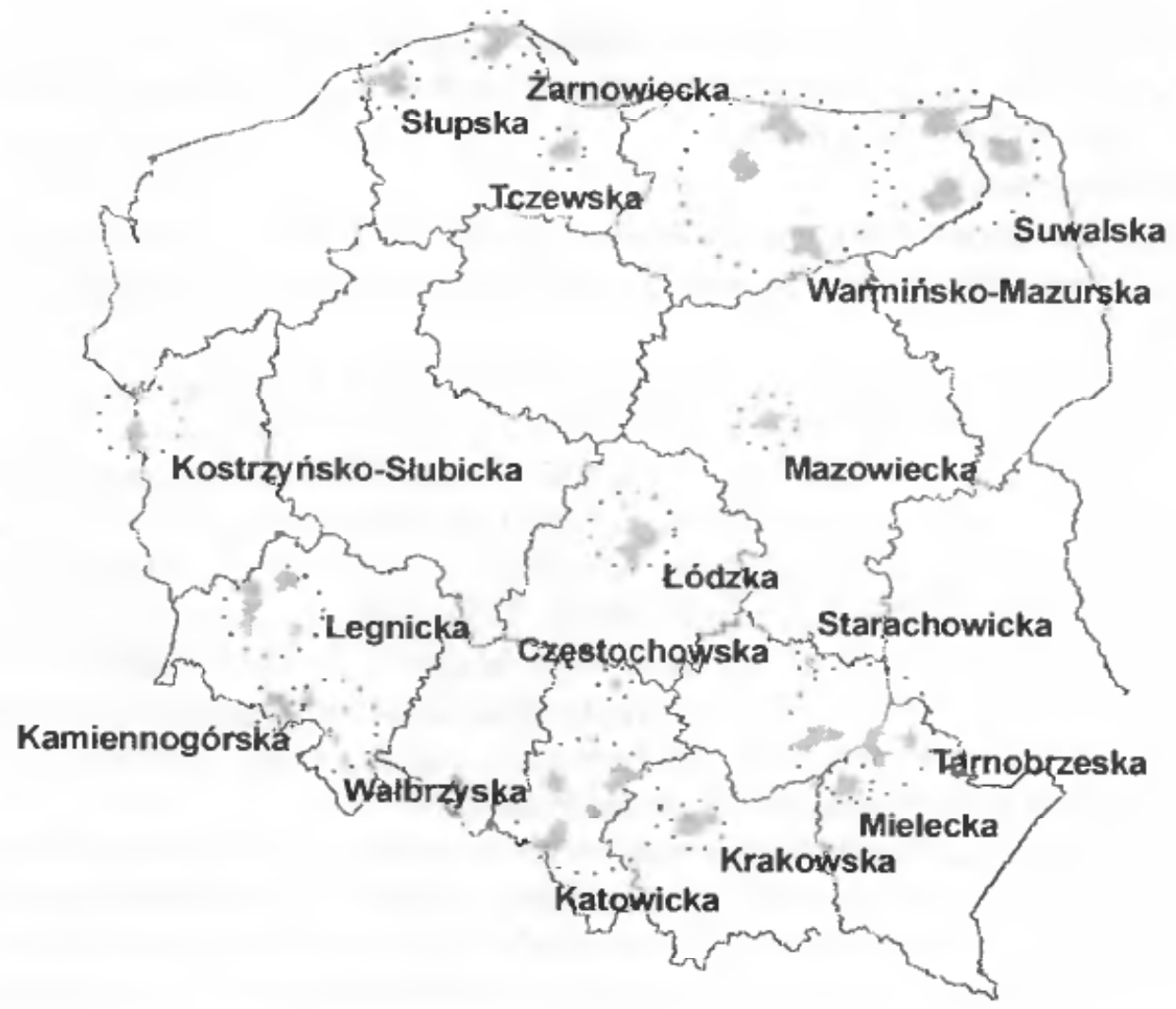

Ryc. 1 Rozmieszczenie specjalnych stref ekonomicznych w Polsce.

Źródło: opracowanie własne

${ }^{4} \mathrm{~W}$ przypadku większości stref zwolnienia w podatku dochodowym otrzymuje się po zainwestowaniu 2 mln ECU (6 stref) lub zatrudnieniu 100 osób (10 stref). 
Pierwsza polska specjalna strefa ekonomiczna powstała we wrześniu 1995 roku w Mielcu (Euro-Park Mielec)5. W 1996 roku powołano kolejne dwie strefy: katowicką i suwalską. Proces tworzenia specjalnych stref ekonomicznych przybrał na sile w 1997 roku. W kwietniu ustanowiono strefy: legnicką łódzka i wałbrzyską, a jesienią dziewięć kolejnych stref: kostrzyńsko-słubicką, słupską, tarnobrzeską, starachowicką, tczewską, warmińsko-mazurską, częstochowską, żarnowiecką i kamiennogórską oraz dwa technoparki w Krakowie i w Modlinie pod Warszawą. Ogółem utworzone strefy zajęły powierzchnię ponad 6 tysięcy hektarów.

Powstałe strefy można podzielić, ze względu na cel, dla realizacji którego zostały powołane. Strefy mogą stanowić:

- Narzędzie restrukturyzacji starych okręgów przemysłowych - Katowicka SSE i Walbrzyska SSE (restrukturyzacja przemysłu wydobywczego węgla kamiennego i związanego z nim przemysłu ciężkiego), Legnicka SSE (dywersyfikacja struktury gospodarczej regionu - monokultura przemysłu związanego $\mathrm{z}$ wydobywaniem i przetwórstwem miedzi), Łódzka SSE (restrukturyzacja przemysłu lekkiego), Tarnobrzeska SSE (dywersyfikacja struktury gospodarczej regionu - monokultura przemysłu związanego z wydobyciem i przetwórstwem siarki), Mielecka SSE (restrukturyzacja Wytwórni Sprzętu Komunikacyjnego PZL - Mielec), Starachowicka SSE (restrukturyzacja Staropolskiego Okręgu Przemysłowego). Ponadto utworzenie stref w starych okręgach przemysłowych umoźliwiało zagospodarowanie niewykorzystanych terenów poprzemysłowych. Ten ostatni aspekt zadecydował też o utworzeniu Żarnowieckiej SSE (tereny po nieukończonej elektrowni atomowej w Żarnowcu).

- Instrument aktywizacji (przyspieszenia rozwoju gospodarczego) regionów o niskim poziomie rozwoju gospodarczego - Suwalska SSE, Warmińsko-Mazurska SSE, Slupska SSE.

- Formę zagospodarowania zaplecza naukowo-badawczego - Krakowski Park Technologiczny, Technopark - Modlin.

- Narzędzie ograniczenia wysokiej stopy bezrobocia strukturalnego: Częstochowska SSE, Tczewska SSE, Kamiennogórska SSE.

- Formę wykorzystania przygranicznego położenia: Kostrzyńsko-Slubicka SSE oraz częściowo Suwalska SSE i Warmińsko-Mazurska SSE.

\footnotetext{
${ }^{5}$ Strefa Euro-Park Mielec jest wzorowana na pierwszej Specjalnej Strefy Ekonomicznej w Europie irlandzkiej Shannon Free Zone, powstałej w 1959 roku, która byłąjedna z pierwszych na świecie stref o charakterze przetwórczo-eksportowym.
} 


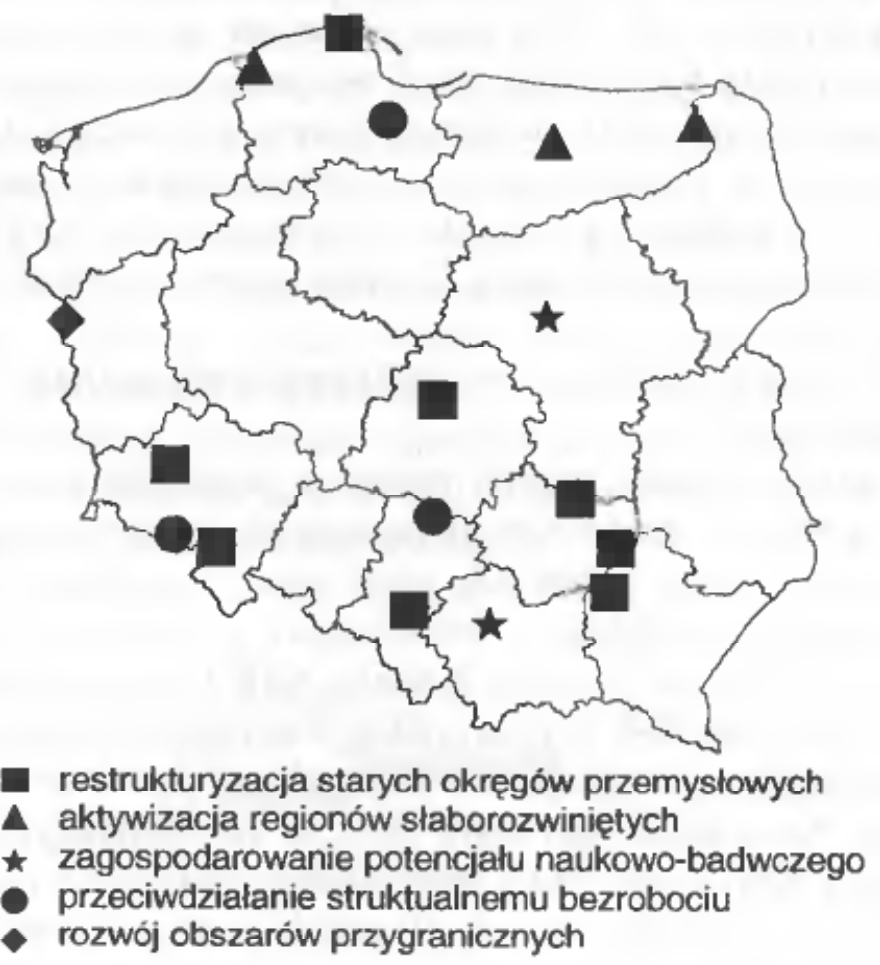

Ryc.4. Klasyfikacja specjalnych stref ekonomicznych

Źródło: opracowanie własne

Powyższa klasyfikacja specjalnych stref ekonomicznych obrazuje zasadnicze różnice występujące między strefami. W przypadku stref z pierwszej grupy można założyć, że mogą one w przyszłości stanowić rzeczywisty instrument wspierania rozwoju regionów. Strefy z grupy drugiej mają szansę przyspieszyć rozwój regionów zacofanych gospodarczo, zaś w przypadku trzeciej istnieje potencjalna szansa na stworzenie na bazie tych stref technoparków. Jednak nie ulega wątpliwości, że strefy z grupy czwartej i piątej zostały powołane wyłącznie w celu rozwiązania problemów lokalnych (głównie poprzez przeciwdziałanie wysokiej stopie bezrobocia), czyli ich działanie nie będzie miało znaczącego wpływu na procesy rozwoju regionalnego.

\section{Inwestycje $w$ specjalnych strefach ekonomicznych na tle przeksztalceń strukturalnych przemysłu Polski}

W założeniach programu powołującego specjalne strefy ekonomiczne zakładano, że na całkowitej powierzchni stref, zajmującej ponad 6 tys. ha (co stanowi około $2 \%$ powierzchni Polski użytkowanej przemysłowo), zatrudnienie znajdzie ponad 175 tys. osób, czyli około $5 \%$ zatrudnionych w przemyśle. Tabela 3 przedstawia obraz realizacji założeń w $15 \mathrm{z} 17$ powołanych stref prawie 5 lat po utworzeniu pierwszej $\mathrm{z}$ nich. 
Tab.3. Efekty funkcjonowania SSE (stan na 30.06.2000)

\begin{tabular}{|c|c|c|c|c|c|c|}
\hline \multirow[t]{2}{*}{ Nazwa strefy } & \multicolumn{2}{|c|}{ Liczba inwestorów } & \multicolumn{2}{|c|}{$\begin{array}{l}\text { Inwestycje } \\
\text { (w mln zl) }\end{array}$} & \multicolumn{2}{|c|}{ Zatrudnicnie } \\
\hline & $\begin{array}{c}\text { Według } \\
\text { zezwoleń }\end{array}$ & $\begin{array}{c}\text { Dzialaja- } \\
\text { cych }\end{array}$ & $\begin{array}{c}\text { Deklarowa- } \\
\text { ne }\end{array}$ & $\begin{array}{c}\text { Zrealizowa- } \\
\text { ne }\end{array}$ & $\begin{array}{c}\text { Deklarowa- } \\
\text { ne }\end{array}$ & $\begin{array}{c}\text { Zrealizowa- } \\
\text { ne }\end{array}$ \\
\hline 1. Mielecka & 37 & 36 & 861,8 & 1225,0 & 4759 & 4820 \\
\hline 2. Katowicka & 49 & 32 & 3173,3 & 2718,3 & 10698 & 6761 \\
\hline 3. Suwalska & 59 & 40 & 181,2 & 210,3 & 3449 & 1653 \\
\hline 4. Legnicka & 14 & 6 & 1111,0 & 632,4 & 3924 & 1329 \\
\hline 5. Lódzka & 20 & 6 & 355,0 & 138,7 & 1846 & 350 \\
\hline 6. Wałbrzyska & 21 & 17 & 518,4 & 198,1 & 4736 & 2993 \\
\hline 7. Kamiennogórska & 9 & 5 & 33,8 & 8,7 & 646 & 232 \\
\hline $\begin{array}{l}\text { 8. Kostrzyńsko - } \\
\text { - Słubicka }\end{array}$ & 20 & 7 & 172,3 & 74,8 & 877 & 183 \\
\hline 9. Słupska & 10 & 6 & 18,5 & 7,9 & 541 & 231 \\
\hline 10. Starachowicka & 17 & 11 & 57,4 & 15,5 & 1275 & 270 \\
\hline 11. Tarnobrzeska & 22 & 19 & 112,7 & 120,6 & 1387 & 1133 \\
\hline 12. Tczewska & 4 & 2 & 185,4 & 102,2 & 1380 & 258 \\
\hline $\begin{array}{l}\text { 13. Warmińsko - } \\
\text { - Mazurska }\end{array}$ & 16 & 3 & 22,6 & 17,3 & 339 & 112 \\
\hline 14. Żarnowiecka & 8 & 5 & 26.4 & 13.6 & 425 & 173 \\
\hline 15. Krakowska & 4 & 0 & 134,9 & 0 & 984 & 0 \\
\hline Ogólem & 310 & 195 & 6964,7 & 5483,4 & 37286 & 20498 \\
\hline
\end{tabular}

*Mazowiecka i Częstochowska SSE nie wzbudzily zainteresowania żadnego z inwestorów, co jest bezpośrednią przyczyną ich likwidacji wraz z wejściem w życie nowelizacji Ustawy o SSE 1 stycznia 2001 roku

Źródło: Opracowanie własne na podstawie danych Ministerstwa Gospodarki 
Do końca czerwca 2000 roku 310 inwestorów zadeklarowało chęć podjęcia działalności gospodarczej na obszarze stref. Deklarowany kapitał oszacowano na $6964,7 \mathrm{mln}$ zł, przy zatrudnieniu ponad 37286 osób $^{6}$. Inwestorzy posiadający zezwolenia zakupili 1078 ha gruntów pod inwestycje, co stanowi $21,6 \%$ ogólnej powierzchni stref ${ }^{7}$. Powyższe zestawienie uświadamia fakt, że wartości przedstawione w programach powołujących strefy (mimo charaktery długookresowego) były mocno przesadzone i nie stanowią wielkości realnych. Zgodnie z szacunkami można oczekiwać, że w polskich strefach zatrudnienie znajdzie jedynie około $1 \%$ pracujących w przemyśle.

Pomimo tak dużych rozbieżności pomiędzy wartościami zakładanymi, a faktycznym zainteresowaniem inwestorów strefami, struktura branżowa poczynionych inwestycji wygląda bardzo korzystnie.

Dominującym typem działalności gospodarczej prowadzonej na obszarze stref jest produkcja pojazdów mechanicznych, przyczep i naczep. W połowie 1999 roku inwestycje w tej branży wyniosły prawie 3 mld zł, co stanowiło $47,2 \%$ ogółu wszystkich inwestycji. Jednocześnie wielkość zatrudnienia $w$ tej branży przekroczyła $30 \%$ ogólnej liczby zatrudnionych w strefach. Produkcja samochodów i akcesoriów samochodowych jest zdominowana głównie przez kapitał zagraniczny. Szacunkowo, określa się, że co piąty inwestor zagraniczny działa właśnie w tej branży.

Kolejną silnie reprezentowaną branżą jest produkcja drewna i wyrobów z tego surowca. Prawie $13 \%$ inwestycji i $11 \%$ zatrudnienia skupiało się w tym dziale. Znaczące pozycje zajmowały również: produkcja chemikaliów, wyrobów chemicznych i włókien sztucznych (11,3\% kapitału, 7,6\% zatrudnienia), produkcja metalowych wyrobów gotowych $(8,6 \%$ kapitału, $10,5 \%$ zatrudnienia), produkcja wyrobów z gumy i tworzyw sztucznych $(6,2 \%$ kapitału, 10,6\% zatrudnienia). Najmniejszą popularnością cieszyły się: produkcja artykułów spożywczych i napojów, produkcja masy celulozowej i papieru, produkcja maszyn i aparatury elektrycznej, produkcja mebli, produkcja maszyn i urządzeń, działalność wydawnicza i poligraficzna, produkcja wyrobów z surowców niemetalicznych. Najsłabiej rozwiniętą branżą była produkcja odzieży, w której zainwestowano zaledwie $0,2 \%$ kapitału, zatrudniając przy tym $1,6 \%$ ogółu pracujących w strefach.

\footnotetext{
${ }^{6}$ Ponad $81 \%$ inwestycji stanowiły przedsięwzięcia podjęte przez kapitał zagraniczny m.in. tak spektakularne jak fabryka General Motors w Gliwicach (wielkość zatrudnienia ponad 2 tys. osób przy wielkości inwestycji równej $1 \mathrm{mld} \mathrm{zl}$ ) $\mathrm{i}$ inwestycja Volkswagena w Legnicy (wartość inwestycji ponad $0,5 \mathrm{mld} \mathrm{zl}$ )

${ }^{7}$ W ogólnej powierzchni stref zwierają się również tereny zajęte przez lotniska (Mielec, Modlin) i obszary przeznaczone na rozbudowę niezbędnej infrastruktury technicznej.
} 

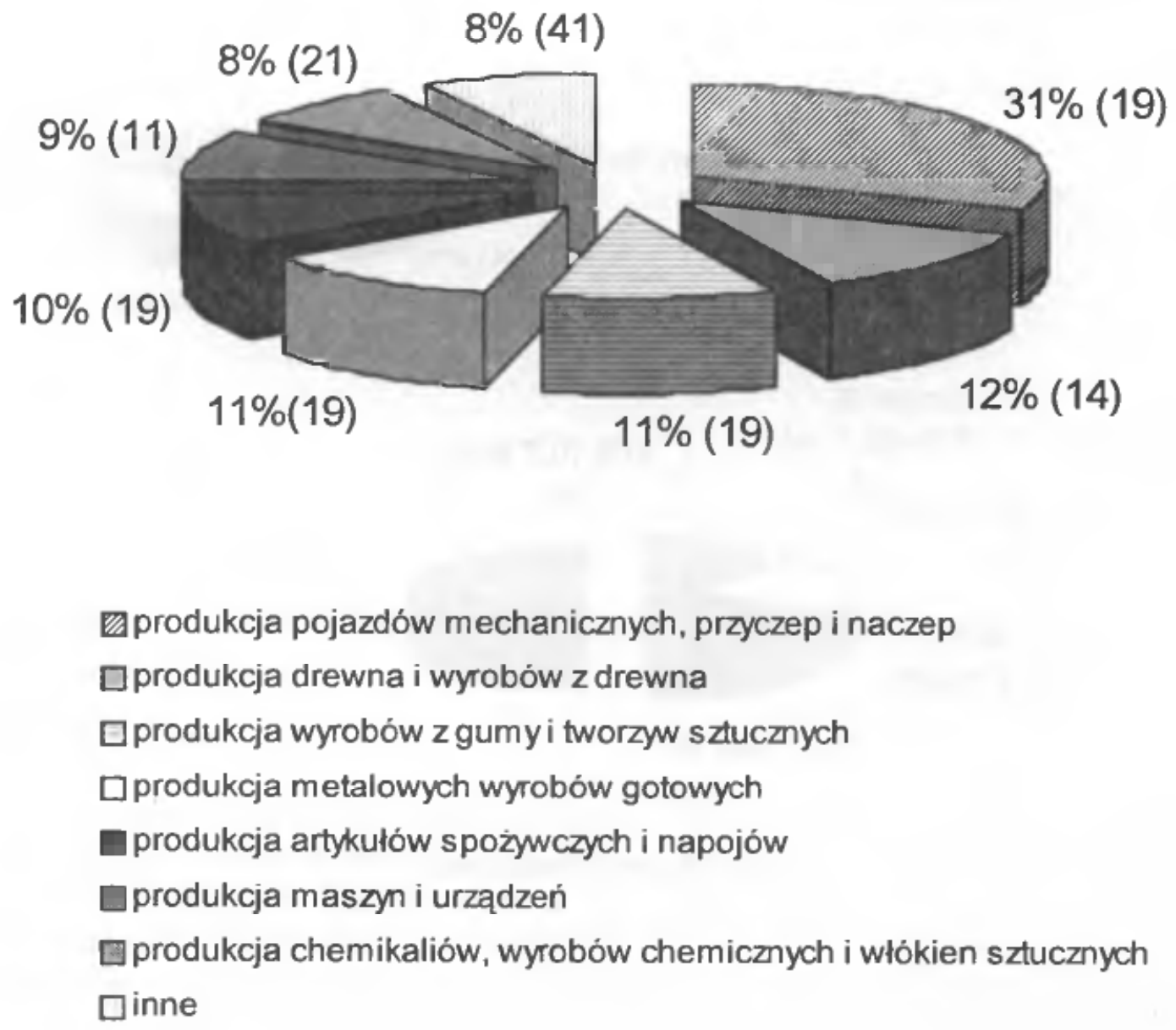

* - udział w ogólnej liczbie zatrudnionych

$(6, \ldots, 14)$ - liczba podmiotów gospodarczych, reprezentujących daną branżę

Ryc.1. Struktura branżowa inwestycji w SSE (stan z 30.06.1999 r.)*

Źródło: opracowanie własne

Z analizy struktury branżowej inwestycji w polskich SSE wynika jednoznacznie, że największym zainteresowaniem przedsiębiorców cieszą się uznane za tzw. „progresywne” branże działalności gospodarczej, przy znacznej dominacji branż „progresywnych, kapitałochłonnych", a więc takich, w których jednocześnie wzrasta zatrudnienie i wydajność pracy (średni koszt stworzenia 1 miejsca pracy - ponad 330 tyś zł). Wśród preferowanych działów za dominującą należy uznać produkcję pojazdów mechanicznych ( $94 \%$ zatrudnionych w tym typie działalności pracowało w branży motoryzacyjnej). Dominacja produkcji środków transportu to głównie zasługa inwestycji zagranicznych koncernów motoryzacyjnych i ich kooperantów. Wśród 20 największych firm zagranicznych, które ulokowały się 
w SSE, aż 12 związanych było z branżą motoryzacyjną ${ }^{8}$. Do największych pracodawców należą: Opel Polska (Katowicka SSE), Lear Corporation (Mielecka SSE), Volkswagen Motor Polska (Legnicka SSE).

\section{Deklarowany kapitał}

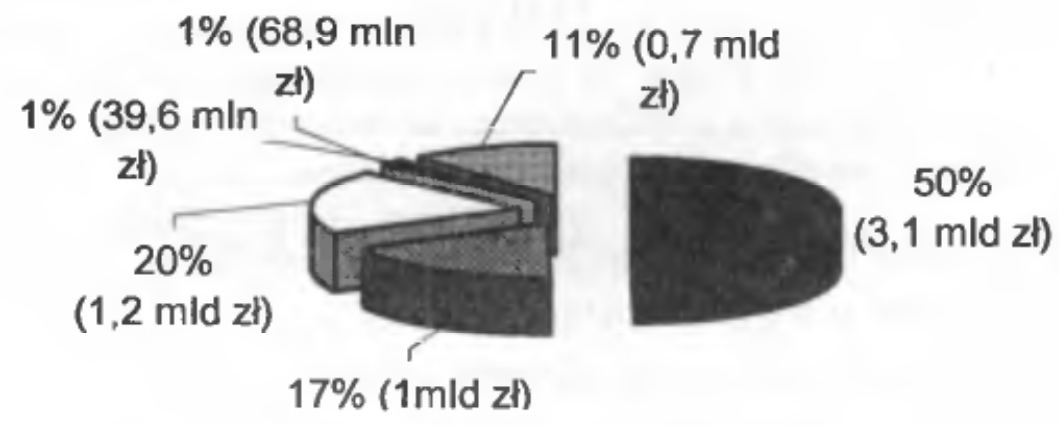

Deklarowane zatrudnienie

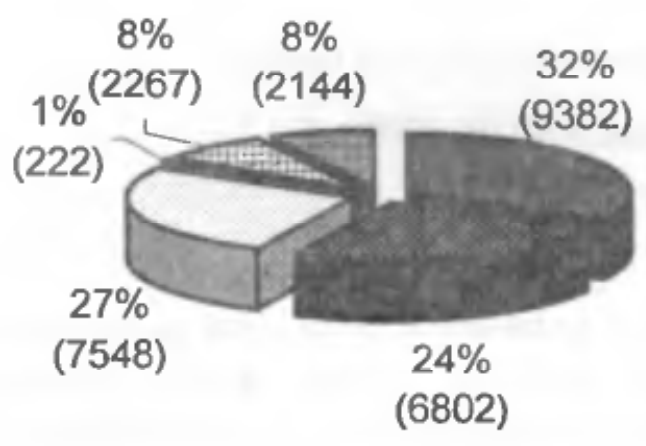

\footnotetext{
${ }^{8}$ Obecność, a tym bardziej dominacja w SSE przedsiębiorstw, działających w branży motoryzacyjnej wzbudza wiele kontrowersji. W krajach Unii Europejskiej produkcja środków transportu należy do tzw. sektora wražliwego i podlega licznym ograniczeniom i restrykcjom.
} 
Liczba inwestorów

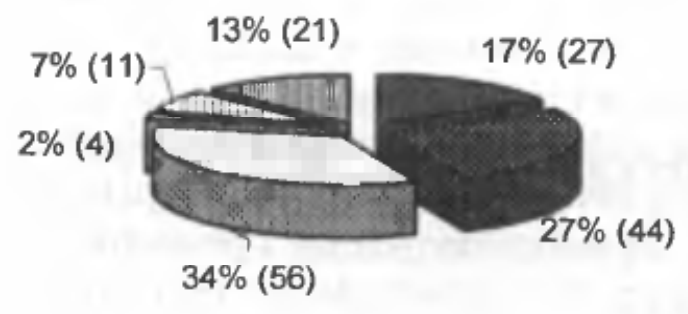

\author{
progresywny, \\ kapitałochłonny \\ progresywny \\ $\square$ progresywny, \\ pracochłonny \\ stabilny \\ ⿴囗十 regresywny, \\ restrukturyzujący się \\ 圆regresywny
}

Ryc. 3,4,5. Działalność produkcyjna w SSE na tle przekształceń strukturalnych w przemyśle Polski (stan z 30.06.1999 r.)

Źródło: Opracowanie własne

Dominacja branż o charakterze progresywnym - kapitałochłonnym jest szczególnie wyraźna w przypadku analiz, w których za podstawę przyjęto wielkość inwestycji (50\% zainwestowanego kapitału) i liczbę zatrudnionych (32\% ogółu zatrudnionych). W przypadku rozpatrywania liczby podmiotów gospodarczych przewaga przedsiębiorstw należących do tego typu maleje. Oznacza to, że deklarowany kapitał i zatrudnienie są skoncentrowane w stosunkowo niewielkiej liczbie dużych przedsiębiorstw. Kooperanci tych przedsiębiorstw działają w branżach sklasyfikowanych jako progresywne i produkują maszyny i aparaturę elektryczną oraz wyroby metalowe używane przy produkcji samochodów.

Mniejsze przedsiębiorstwa z przewagą kapitału polskiego wybierają branże nie wymagające dużych nakładów kapitałowych, za to wykorzystujące duże zasoby taniej siły roboczej. W typologii typ ten nazwano progresywnym pracochłonnym. Stworzenie miejsca pracy na terenie stref nie wymaga ponoszenia dużych nakładów (np. w strefie suwalskiej zdominowanej przez tego rodzaju przedsiębiorstwa jest to 53 tys. zł podczas gdy w katowickiej 300 tys. zł) Niewielka kapitałochłonność prowadzonych inwestycji (dwudziestu trzech inwestorów działających w tym typie branż zadeklarowało inwestycje poniżej $2 \mathrm{mln}$ złotych) przy założeniu tymczasowego charakteru stref (20 lat) może znacznie ułatwić przedsiębiorcom decyzje o likwidacji i przeniesieniu działalności gospodarczej w miejsce o korzystniejszych warunkach lokalizacyjnych.

Wart podkreślenia jest również fakt, że inwestorzy wykazywali mniejsze zainteresowanie działami produkcji uznanymi za stabilne i regresywne. Marginalne znaczenie miały produkcja maszyn i urządzeń ( $8 \%$ ogółu zatrudnionych), produkcja chemikaliów, wyrobów chemicznych i tworzyw sztucznych (7,6\% ogółu zatrudnionych) oraz produkcja wyrobów z surowców niemetalicznych $(0,8 \%$ zatrudnionych). Przekształcenia tych branż odbywają 
i odbywać się będą bez znaczącego udziału stref w oparciu o istniejący już wcześniej potencjał produkcyjny.

Preferencje inwestorów pokrywają się $\mathrm{z}$ trendami obserwowanymi w całym polskim przemyśle. Inwestycje w strefach będą przyczyniać się do utrwalania obserwowanych przekształceń strukturalnych w przemyśle. Należy pamiętać, że strefy faktycznie zaczęły funkcjonować w 1996 roku, a więc zaangażowanie inwestorów w działalność przemysłową w latach 1996 - 1998 było stosunkowo niewielkie i miało marginalną rolę w transformacji przemysłu. Efekty inwestycji w strefach będą widoczne dopiero po kilku latach od utworzenia stref. Już teraz można powiedzieć, że pogłębią widoczny trend rozwoju branż sklasyfikowanych jako progresywne, zarówno tych kapitałochłonnych jak i pracochłonnych. Nie będą miały natomiast znaczenia dla branż, w których następuje głębsza restrukturyzacja, co może świadczyć o mniej korzystnych warunkach do prowadzenia w nich działalności.

\section{Literatura}

Bazydło, A., Smętkowski, M. (2000) Specjalne strefy ekonomiczne - światowe zróżnicowanie instrumentu [w:] Kryńska, E. Polskie specjalne strefy ekonomiczne, Wydawnictwo Naukowe Scholar, Warszawa

GUS, (1999), Rocznik Statystyczny, Warszawa

GUS, (1999), Rocznik Statystyczny Przemystu, Warszawa

Karpiński, A., Pajestka, J., Perczyński, A. (1994) Polityka przemyslowa a procesy dostosowawcze do Wspólnoty Europejskiej [w:] Rola polityki państwa w procesach dostosowawczych do Wspólnoty Europejskiej, ELIPSA, Warszawa

Korenik, S. (1998) Uwarunkowania ekonomiczne tworzenia specjalnych stref ekonomicznych [w:] Obrębalski M., Gospodarka lokalna w teorii i praktyce, Wydawnictwo Akademii Ekonomicznej im. Oskara Langego, Wrocław

Kryńska, E. (red.), (2000) Polskie specjalne strefy ekonomiczne - zamierzenia i efekty, Wydawnictwo Naukowe Scholar, Warszawa

Ministerstwo Gospodarki (1997) Koncepcja tworzenia i funkcjonowania specjalnych stref ekonomicznych w Polsce, Warszawa

Ministerstwo Gospodarki (1998) Specjalne strefy ekonomiczne w Polsce, Warszawa

Ministerstwo Gospodarki (1999) Koncepcja średniookresowego rozwoju gospodarczego kraju do 2002 roku, Warszawa

Mokrzyc, M. (1998) Funkcjonowanie specjalnych stref ekonomicznych w Polsce, Gospodarka Narodowa nr 8-9

Owczarski, M. 1997, „Specjalne strefy ekonomiczne - zagadnienia praktyczne”, Inwestia Sp. z o.o., Katowice 